\title{
Stories of Loss and Healing: Connecting Non- Economic Losses and Damages with Gendered Wellbeing Erosion in the Asia-Pacific Region
}

Sonja Ayeb-Karlsson ( $\sim$ sonja.rosina.ayeb@gmail.com )

University of Sussex https://orcid.org/0000-0001-6124-2730

Alvin Chandra

UQ: The University of Queensland

Karen E. McNamara

UQ: The University of Queensland

\section{Research Article}

Keywords: Climate change, disasters, mental health, non-economic loss and damage, storytelling, sustainable development

Posted Date: April 5th, 2021

DOl: https://doi.org/10.21203/rs.3.rs-341515/v1

License: (9) This work is licensed under a Creative Commons Attribution 4.0 International License. Read Full License 


\section{Abstract}

It is well-known that the climatic impacts affect women and men differently. However, more empirical evidence illustrating how, where, when and who are needed to help address gendered vulnerability. Specifically, research investigating the connections between mental health, wellbeing, and climate change can foster responses to avert, minimise and address loss and damage impacts on vulnerable populations. Few studies explore climate-induced mental health impacts, although this is a crucial area for the conceptual framing of non-economic loss and damage. Declining mental health and wellbeing is at the core of non-economic losses taking place all over the world. The existing literature body recognises the disproportionate environmental impacts on women, this study explores non-economic loss related to mental health and wellbeing for women in the Global South. The article uses empirical storytelling and narratives gathered through field work conducted in Bangladesh, Fiji and Vanuatu. The research findings described how climate change risks and extreme weather events negatively impacts women's mental health and wellbeing, while providing proactive recommendations to address the gendered mental health consequences of climate change.

\section{Introduction}

The impacts of climate change affect the health and wellbeing[1] of women and men in different ways (Rashid and Michaud 2000; Binu et al. 2008; Cutter 2017). Women, children and the elderly face greater risks of developing mental illness and are more likely to become economically disadvantaged following natural hazards (Jordan et al. 2018; Hayward and Ayeb-Karlsson 2021). Gender is a key factor contributing to climate vulnerability, and mental health related consequences for women including depression, anxiety and post-traumatic stress disorder (Clayton et. al. 2015; Ayeb-Karlsson 2020a, 2020b; Kelman et al. 2021). Understanding the root causes of gender vulnerability in relation to specific natural hazards can help illustrate the ways in which women (and other social groups) are made more vulnerable to climatic stress (Wisner et al. 2004; Juran and Trivedi 2015). Similarly, more people-centred research efforts investigating the connections between environmental impacts and wellbeing are required to better prepare and protect the world's most marginalised populations.

To date, limited number of studies explore climate-induced mental health impacts (Watts et al. 2018, 2021; WHO 2018; IPCC 2018; Ayeb-Karlsson 2020a, 2020b; Kelman et al. 2021). This includes the literature around 'solastalgia' and the distress people experience as their local environment changes (Adger 2003; Albrecht et al. 2007; Tschakert et al. 2013; Butler et al., 2014), and studies on 'eco-anxiety, depression and anger' or 'ecological grief and despair' (Willox 2012; Cunsolo and Ellis 2018; Stanley et al. 2021). Furthermore, research on female experiences of wellbeing and climatic stress is scarce. This is concerning as various scholars for decades have drawn attention to the lack of critical studies investigating gender vulnerability in the area of climate change (Rivers 1982; Fothergill 1996; Enarson 1998; Alam and Rahman 2014). 
Science and policy negotiations on Loss and Damage[2] have evolved at the UNFCCC, with Article 8 of the Paris Agreement on Climate Change explicitly requiring the urgent need to address non-economic loss and damage that often disproportionately impacts vulnerable populations (UNFCCC 2015; McNamara et al. 2021). Empirical cases from vulnerable societies illustrate the increasing severity of environmental and climatic impacts on people with likely limits to adapt (Huggel et al. 2015; Barnett et al. 2015; Mechler and Schinko 2016). In an attempt to conceptualise and capture the non-financial losses that money cannot buy back, a body of work describing Non-Economic Losses and Damages (NELs or NELDs) associated with the impacts of climate change is gaining ground (Barnett et al. 2016; Tschakert et al. $2017,2019)$. NELDs refer to the climate-related losses that cannot be traded easily in the market, are inclusive of both material and non-material losses, and experienced by the most affected by climate change (UNFCCC 2013; Morrisey and Oliver-Smith 2013). NELD impacts reported in the literature to date include elements that cannot be easily economically monetised such as loss of cultural heritage, human health and lives, local knowledge, as well as human displacement and mobility (Barnett et al. 2016; McNamara et al. 2016, 2021; Preston 2017).

The current Non-Economic Loss and Damage literature body mainly focusses on the theoretical development of the field, given the contested normative, technical and political issues surrounding the concept (Boyd et al. 2017; McNamara et al. 2019). The inattention to specific losses suffered by women and men is of particular concern to the framing of the concept given the evidence on gendered vulnerability to climate change. A gendered lens can aid in articulating the channels through which losses can entrench vulnerability and make good adaptation decisions to reduce the risk of non-economic losses.

Even though the literature suggests that climate variability and change negatively impact women's mental wellbeing, cases illustrating how this is manifested as well as empirical evidence of noneconomic losses among vulnerable countries and populations are scarce (Barnett et al. 2016; Boyd et al. 2017). The connections between gender, wellbeing and climate change is likely to engender the policy framing of Non-Economic Loss and Damage. This article therefore provides valuable empirical contributions on how environmental impacts influence women's health, wellbeing and healing[3] processes using cases from Bangladesh, Fiji and Vanuatu.

\section{Footnote:}

[1] In this article, 'wellbeing' refers to "a subjective and dynamic state of feeling healthy and happy that ties into life satisfaction and influences a person's (or a collective's) psychological and social function" (Ayeb-Karlsson 2020c:2).

[2] In this article, Loss and Damage, and Non-Economic Loss and Damage refer to the two concepts (noun), while loss and damage and non-economic losses are used to refer to when something is lost or damaged (adjective) as well as the action of something being lost or damaged (verb). 
[3] In this article, we understand healing as a wider social and psychological process of making and becoming healthy, happy and well again. This process includes elements such as collectively rebuilding what was damaged, grief and recover what was lost, or putting words on and working through traumatic experiences.

\section{Mental Health And Climate Policy}

The IPCC has over the last decades been clear and coherent in their message. As climate change impacts and disasters are becoming more frequent and intense, they are likely to affect the world's vulnerable populations the most (IPCC 2014, 2018). Meanwhile, broader registers within academia, policy and climate action align these climatic impacts to human health (Watts et al. 2018, 2021; WHO 2018; NRC 2019). Most academic literature, however, focusses on specific regions or disasters and few studies describe the connections between mental health and climate change (Hunter et al. 2015a; Rataj et al. 2016; Berry 2018; Piguet et al. 2018).

Climate change can affect human health directly and indirectly. The direct health impacts include the effects of exposure to higher temperatures, such as respiratory diseases, to injuries and death due to extreme weather events, such as droughts, floods, heatwaves, and storms. The indirect effects on health can be linked to ecological changes or societal responses, and include food and water insecurity, or population displacement and reduced access to health services (Watts 2018, 2021; WHO 2018). People migrating away from climatic stress for example, often end up moving from rural to urban areas and find themselves settling down in informal settlements upon arriving in the cities (Hunter et al. 2015b; Etzold 2016; Adri and Simon 2018; Ayeb-Karlsson 2020b). Life and work in these informal settlements tend to place people in higher risk of developing health issues (Ayeb-Karlsson et al. 2016, 2020; Ezeh et al. 2017; Schwerdtle et al. 2018). The slums are often overcrowded with weak public health services and lack infrastructure providing access to clean water and sanitation (Unger and Lee 2007; Butala et al. 2010; Wekesa et al. 2011). The unhealthy living environment poses physical and mental health risks, such as depression, anxiety, trauma and increased incidents of violent or abusive behaviour (Cattaneo et al. 2009; Gruebner et al. 2011, 2012; Mberu et al. 2015).

Health and wellbeing have become a key area of interest within most climate and sustainability policy frameworks. For example, the Millennium Development Goals have gone from child mortality, maternal health and diseases to good health and wellbeing (SDG3), or climate action (SDG13). Meanwhile, the Sendai Framework for Disaster Risk Reduction and Resilience aims to reduce 'losses in lives, livelihoods and health', while Article 8.1 in the Paris Agreement 'recognize the importance of adverting, minimizing and addressing loss and damage associated with the adverse effects of climate change, including extreme weather events, slow onset events, and the role of sustainable development in reducing the risk of loss and damage'(Le Blanc 2015; UNFCCC 2015; UNDRR 2015: 6).

From a UNFCCC policy perspective, mental health can provide an understanding on how climate-induced non-economic losses can lock vulnerable populations in positions of lasting wellbeing erosion. In recent 
years, the literature around Non-Economic Losses and Damages has rapidly increased. Similarly, to the Loss and Damage discourse, Small Island Developing States are becoming a leading voice within the non-economic narrative (Roberts and Huq 2015; Kelman 2015; McNamra et la. 2021). However, wellfounded concerns have pointed out how a normalisation of loss could be working against effective mitigation and adaptation preparedness rather than speeding it up (Farbotko and Lazrus 2012; Methmann and Oels 2015; Barnett 2017). This article extends on the hypothesis that by matching climate-induced losses with a human face, voice, and storyline, we work against such normalisation and generalisation (Ayeb-Karlsson et al, 2016; Tschakert et al. 2019; Conway et al. 2019).

\section{Case Studies}

The article builds upon three qualitative empirical case studies gathered through storytelling methodologies (using ethnography and involving individual and focus group discussions) in Bangladesh, the Fiji and Vanuatu islands. The authors conducted the field studies between the years of 2010 and 2018 , which were part of different climate vulnerability research programmes. The selected peoplecentred methodological narrative approach of personal life stories within the area of climate change research is still rare but slowly growing (Ayeb-Karlsson et al. 2016, 2019; Conway et al. 2019; Singh 2018, 2019). The few studies investigating mental ill-health in relation to climatic impacts and natural hazards, however, often do so by the use of survey questionnaires or mental health assessments aiming to quantify the extent of the impacts (Adeola 2009; Davis et al. 2010; Paul et al. 2011). These research designs may not necessarily be the most effective in capturing the longer-term, non-linear, and complex casual mental health impacts that follow extreme weather events and climatic stress. This is a serious concern as mental wellbeing is at the very core of the three global 2015 policy frameworks.

The identified storylines describe the impacts of climatic changes upon women's mental wellbeing that are often disproportionate to other social groups. A storytelling approach is an effective way to research mental health as the wellbeing impacts often are difficult to register and to quantify. Unlike physical illhealth, mental ill-health builds on causal psychosocial relations. After hurricane Katrina, for example, researchers found that many women did not develop mental ill-health impacts, such as depression, anxiety, acute stress disorder and PTSD, until one to two years after the strike (Binu et al. 2008; Rhodes et al. 2010). The proposed research design therefore provides a comprehensive way of informing climate policy of the potential non-economic losses and damages that are associated with climatic changes.

\subsection{The case of Bangladesh: Gendered (im)mobility and wellbeing erosion}

Bangladesh's geographical position in the world's largest delta supports the sustainability of a dense population while simultaneously exposing people to a variety of environmental impacts (Penning-Rowsell et al 2013; Ayeb-Karlsson et al. 2016). Moving away from environmental risk, whether longer-term or shorter-term, through temporary, seasonal and permanent migration or sudden evacuation, is one of the oldest and most common adaptation strategies on earth. The stories encountered in Bangladesh cover gendered experiences of rural-urban migration as well as gendered immobility.[4] The narratives included 
women's (im)mobility opportunities while dealing with environmental stress, as well as their (im)mobility spectrum after having migrated to to the cities. The living conditions in the informal settlements often contributed to a lower quality of life (including struggles with mental ill-health) where women, girls, but also children overall, faced social risks that often did not apply to adult men (Mullick and Goodman 2005; Izutzu et al. 2006; Khan and Flora 2017).

\subsubsection{Gendered activities and spaces}

The storytelling sessions described a social shift that came with starting to work outside of the house after having been a housewife. Some women felt that this provided them with a new exciting opportunity, but others felt that it came with a loss of identity, value and honour. In some of the narratives it was explained that women tending to outside work represented a step away from God's righteous path which could even be punished:

\section{Extract 1}

Why are there so many disasters? Because we must have left his [Allah's] path. Women are working outside the house and going here and there. This is not good. We have to return to his path. Otherwise, we will have to face the consequences. The cyclone shelter will not be able to save us then. I can feel that the weather is changing. I think it is happening because we forgot about Allah. It is the punishment of Allah. /.../ The cyclone strikes are holy creations. The same way God created man, he created cyclones. Therefore, God will decide how they will affect you. Those who have done him right, and who have followed in his footsteps will be put in safety (Ayeb-Karlsson et al. 2019:763).

Some women felt that their social value decreased with the labour activities. They were no longer considered as honourable or healthy. One woman, for example, explained that she believed that her and her daughter's health issues were a consequence of the income earning activities. It was a punishment for the housemaid work:

\section{Extract 2}

I do not know what disease my daughter has. Not even the doctor was able to understand what kind of sickness it is. She has fevers, but it does not show all the time. We got sick from doing household work in other people's houses. That is how we got the disease (Ayeb-Karlsson 2020b: 8).

Besides domestic work, many of the migrant women turned to the surrounding garment factories. The slums often formed around the factory locations as they provided job opportunities to the new settlers. However, the risky working conditions in Dhaka's garment factories have received internationally attention through, for example, the 2012 garment factory fire and the 2013 Rana Plaza collapse. Recent studies also show an association between climate-induced female migration, garment factory work, and violence or abuse leading to depression (Akhter et al. 2017; Parvin et al. 2018; De and Murshid 2018; Fitch et al. 
2018; Rahaman et al. 2018). These gendered risk were also delicately described in the storytelling sessions:

\section{Extract 3}

It is very rare for a girl to go to Dhaka alone. One girl in hundred perhaps goes alone. What generally happens is that after some time her character changes. She ends up marring someone and forgets about her family. If a girl moves to Dhaka for work, she should keep in mind that she has to send money to her parents, and that she must wait to marry until her parents want her to do so. If she forgets this and gets into a relationship with a man, marries him and starts a new family, she may suffer in the long run. Girls often meet men in the garment factories and start a relationship, but the husband may leave her even after she has had his child. This is the punishment for marring someone without knowing enough about him. The first six months or so the husband may behave well, but then, what generally happens is that he changes. It is the girl then who has to suffer. In this situation, she can no longer go back home to her parents - she will have to work to provide and care for his child. She will have to work alone to support herself and her child. Perhaps she keeps her child somewhere under a tree while she works, and when the child cries, she comes running to calm her down. That is what her life has become, miserable. If she only would have listed to what her parents said and kept to her work, she would not have to face such a reality. Though she only cared about herself and ended up ruining her life instead. / ... / A man can surely get married again, even a girl if she is a dreamer. She could get married to another man too. Though it is the child who suffers the most in this kind of situation. A mother can re-marry with the child, or she can leave the child behind. / ... / The mother got another husband, the father got another wife, but what is there for the child? What did she get out of all this? Shame and hatred! This is why the child suffers the most (Ayeb-Karlsson 2020b:6).

\section{Extract 4}

A father can leave his children, but a mother can never leave her child. I had hoped that my children would help me in my future days. I was very sad when I found out that my children neglected these duties. I have no stable happiness in my life. I was forced to nourish them poorly, so now they are not that sound either (Ayeb-Karlsson 2020b:7).

The narratives were captured in Bhola Slum, hosting settlers from Bhola Island due to the devastating 1970 Bhola cyclone and more recently erosion (McNamara et al. 2016; Ayeb-Karlsson et al. 2016, 2020),

A limited number of studies link low wellbeing erosion in Bangladesh to climate-induced mobility and displacement in the slums of Dhaka and Khulna (Ruback et al. 2002, 2004; Rahaman et al. 2018). The longer-term causal relations leading up to the lower life-satisfaction are complex and difficult to capture. Young and unmarried women face additional social and gendered risks in the factories that through shame and stigmatisation can have serious implications on their mental wellbeing. This stigma can also be passed along to their children or even the next generation. In this way, marrying the 'wrong man' may end up costing a woman a lifetime of sadness that only God will be able to save her from: 


\section{Extract 5}

If there was any chance to live a better life where my children had the opportunity to work, then I would go back to the village [on Bhola Island]. However, I was left by my husband, and then I got sick. I do not have any hope left for my future. / ... / Life was good until my husband got re-married. My husband used to treat me well. I was very happy until he married again. / ... / It is unbearable to utter the words of my miserable story to you. I never want to speak of them. My husband married three other women besides me. You cannot do anything to relieve my sadness or misery. Only Allah can help me. (Ayeb-Karlsson 2020b:7).

Child marriage is described as a common way for household to cope with income loss, food insecurity and poverty. It however came with serious implications for the girls. One woman, for example, describe struggling with health issues and kidney damage after giving birth to her son at a very young age. She seeks medical attention and end up visiting a female doctor. She gets sent home to notify her husband. He needs to attend the hospital to receive her diagnosis. However, he never tells her what is wrong. Instead, he tries saving up enough money to get her the treatment that she needs:

\section{Extract 6}

I got married when I was twelve years old. A few years later I gave birth to my first son. I faced a lot of problems giving birth to him. / ... / A woman from work was a doctor so she took me to Dhaka Medical Hospital. There they did some tests and noticed that my kidneys were failing. She gave me an injection and told me that I had to go home and ask my husband to meet with her. Then she gave me some pills and sent me home. I told my husband that he should go and met with her. She was the one who notified my husband about my kidney failure, but she never told me what was wrong. My husband looked worried when he returned home so I tried to find out why, but he never told me what was wrong. He just started to work really hard, saved up money, and even took out a loan. The family I worked for at the time also gave us some money. / ... / At one point when I was sick and he could not do enough, he even thought of selling his blood, but I warned him not to do so. He does not have that much blood so he would surely have died. If we are both dead then who would look after our children? (Ayeb-Karlsson 2020b:7).

In his efforts to gather enough money for her treatment, the husband also ends up getting unwell. The family is now struggling financially and are therefore forced to take out a loan. When this is not enough to cover the treatment, the husband even considers selling his blood. These difficult circumstances put tremendous strain and emotional pressure on the wellbeing of the whole family. A family where both parents are worrying about whether they will survive long enough to raise their children, while the children are terrified of losing their mother as well as their father. The woman explains how it is not that common to marry your daughter away at the bare age of 12 , but her household struggled too with health issues and poverty. At one point, her parents could not afford to keep her within the family any longer. She had to marry as it would alleviate food- and household expenses. 
Physical and mental health are closely interlinked. Life in the informal settlements go hand in hand with difficult living- and working conditions that contribute to the wellbeing erosion. People end up facing health issues that sometimes stretch over a lifetime as a result of, for example, work related injuries or the poor dwelling. A large extent of their income then has to pay for the medicine and medical attention, or people get forced into debt. Child marriage is therefore often used as a desperate financial coping strategy, but it ends up resulting in a lifelong erosion of the girls' mental wellbeing. It becomes a vicious cycle of poverty, physical- and mental ill-health, where poverty aggravates physical and mental ill-health which in turn exaggerate poverty.

\subsubsection{Gendered disaster loss and healing}

In relation to gendered disaster (im)mobility, the narratives explained that women and children were more vulnerable than men during the cyclone strikes. For example, more women and children died as they did not know how to swim. Women also sometimes got stuck in trees and branches with their hair and clothing or drowned as they were trying to save their children:

\section{Extract 7}

Women and children are mentally weak. They get afraid easily. Children cannot swim so sometimes mothers hold onto their children, and that may cause the death of them both. Men are brave and have often faced the storm out on the sea, while women have not lived through experiences outside of the house (Ayeb-Karlsson 2020a:6).

\section{Extract 8}

Women die because of their hair and clothing. They are also emotionally weak. Children are always fond of their mothers. Women cannot leave them during such an event. That is why they too become victims of the disaster (Ayeb-Karlsson 2020a:6).

Adding to this, gendered immobility itself put women, and particularly unmarried adolescent women and girls, at increased risk during the cyclones. As poor families feared that sexual harassment and genderbased violence could ruin their chance to marry and put the household at financial risk, they sometimes believed it was safer for them to stay behind and not evacuate to the shelters:

\section{Extract 9}

It is not right [for unmarried women to go to the shelter] because it could create problems./ ... / do not like women going to the shelter. It just does not feel right. Wherever they go, things happen (Ayeb-Karlsson 2020a:6).

The economic- and non-economic losses that people faced due to the cyclones were delicately described in the sessions. The loss of mental health and wellbeing were key factors that people themselves 
highlighted as some of the most important non-monetary losses:

\section{Extract 10}

These hazards keep coming back every year. Besides the mental traumas that they leave behind, the worst impact upon people is the loss of human lives on an annual basis. Money and time can reduce damages, but they cannot return a lost life. / ... / Physical damage and the loss of resources that were emotionally important to us are unforgettable losses. / ... / Some internal losses may also take place. / ... / During the cyclones, some people get injured internally. Injured within such an important organ that he or she may face complications afterwards. They may approach doctors and seek medical treatment in secret, but some losses cannot be healed by doctors. / ... / People face mental issues because of these traumas. Family problems arise as a result, and they grow larger by each day. However, when we talk about floods, it is often the economy that receives the most importance. / ... / The only doctors that came to see us [after the cyclone] were [physical] medical specialists. They were not able to give mental or psychological support to the victims here. / ... / We noticed that some children would bury their toys after here and there. / ... / From the children's behaviour we sensed their fear. They often repeated: 'When will the flood strike again? Will I have to go [to the shelter] again then, or will I die next time? If it happens again, then please promise me not to leave me'. / ... / The parents reassured their children that the flood will not come back, and that they should go back to living life in the way they had done before the disaster stroke (Ayeb-Karlsson 2020a:8-9).

People described these wellbeing losses and damages as internal injuries in an important organ that could not be healed by doctors despite seeking medical attention. The narratives explained the severity of these wellbeing losses and damages, that impacted whole families and societies but women and children particularly hard. Research show how gender-based violence and sexual abuse increase in the aftermath of the cyclones in Bangladesh (Akhter et al. 2015; Ahmed et al. 2019; Rezwana and Pain 2020; Haywards and Ayeb-Karlsson 2021). Yet, mental health services are not part of the post-disaster assistance. The lack of professional mental health workers to support the healing of post-traumatic stress, as explained, resulted in serious long-term, wider and exaggerated wellbeing impacts.

In the absence of mental health services to support people's healing processes many turned to religion in an attempt to deal with fear, uncertainty and to come to terms with the losses that they had experienced:

\section{Extract 11}

When the cyclone strikes, nobody cares about others. People think about themselves. Normally, girls face more problems during the cyclones because of how they dress. They may also get hurt, on their hands, legs, or other body parts. Sometimes, trees even fall on top of people and they die. I know of a mass grave. I have seen many dead bodies in my life due to the cyclones. The people buried there did not even get proper burial clothes. Everyone's lifetime has already been decided upon by God. Allah decides whether you will die or live (Ayeb-Karlsson 2020a:8). 


\section{Extract 12}

No one can save us but Allah. The NGOs [non-governmental organisations] cannot do anything. If Allah does not want you to survive, all your efforts will be in vain and you will die. We must follow Allah /.../.

During a cyclone, it is Allah's wish that will determine if my house is protected. It is first when my house collapses that I will come out (Ayeb-Karlsson et al. 2019:762).

\section{Extract 13}

When I think about why I survived that day, the day of Sidr, why I did not drown although the flood pulled me away. There is only one answer: Allah looked after me. Allah kept me safe (Ayeb-Karlsson et al. 2019:762).

\section{Extract 14}

I am not afraid. If Allah wants to take me, he could easily do so. What is the point of being afraid? It is out of my hand just like the grief that my land went into the river. It was Allah's property, and he took it away. This is not a problem as he is the one who keeps us alive. He will make sure to feed us. If another cyclone strikes, there is nowhere to go since we lost our land on which we could have rebuilt our houses. You still have to keep your faith in Allah, and wait out the cyclones patiently in your room. What else can you do? This is our story, the story of every single person in this village (Ayeb-Karlsson et al. 2019:762).

\section{Extract 15}

It is all left in Allah's hands, who will survive and who will die. For example, in this village a mother and a child who were running towards the shelter got hit and separated by the storm surge. Later on, the mother felt some hair touching her feet in the water only to realise that it was her child. She grabbed hold of a tree to survive. When the storm stopped, people found her sitting in the top of that tree with her child. People think that this is a miracle, that she and her child survived the cyclone. It all depends on Allah (Ayeb-Karlsson 2020a:8).

In this way, God became a source for healing and people put their faith in this greater power that would protect and save those who believed. Religion therefore gave people a belief system that made it easier for them to carry on living with the cyclones.

\subsection{The case of the Fiji Islands: Women and children at risk of violence}

In Fiji, the narratives describe how food insecure women and children (due to social exclusion and lack of financial resources) are more at risk of facing violent behaviour and sexual abuse after cyclones and floods. Fiji's location in the South Pacific as a Small Island Developing State (SIDS) makes it highly vulnerable to both seasonal and interannual variations in climate. With an area of $18,000 \mathrm{~km}^{2}$ spread across 332 islands (110 are inhabited), the country faces enormous development and environment 
challenges. The majority of the 912,241 people live on two large islands, Viti Levu and Vanua (UN 2019). Impacts from natural hazards and climate change represent a major obstacle to achieving economic and development goals. Annual floods, tropical cyclones, storm surges and coastal inundation significantly affect GDP growth. The largest cyclone to hit Fiji in 2016 was the category 5 Tropical Cyclone (TC) Winston that impacted over $40 \%$ of the population and resulted in US\$2 billion (20\% of GDP) in damages across key sectors (GoF 2017). Climate impacts such as sea-level rise, ocean acidification, increased risk of flood or the spread of vector-borne diseases into new areas have been documented across many settlements in Fiji (Nolet 2016; Orcherton et al. 2017; Piggott-McKellar et al. 2019).

\subsubsection{Sexual violence in disaster events}

Women, children, and minority groups in Fiji are more vulnerable to and face disproportionate environmental impacts. For example, an estimated 120,000 children under 18 years were affected, and 36,000 of these children are under 5 years of age as a result of Tropical Cyclone Winston. About 5,600 women in the affected areas were pregnant and estimates indicated that about 600 births were likely in months following the TC (Live and Learn and CARE 2016). Recalling the impact of 2009 floods, one female NGO staff described concerns relating to women and girl child's relocation to evacuation centres that include over overcrowding, lack of privacy, and lack of security:

\section{Extract 16}

Another way it affects women and girl child, is through their displacement to flood evacuation centres from homes. In Fiji, most of these evacuation centres are in schools or community halls which cannot adequately cater for female reproductive rights. The evacuation centres are not able to take care of pregnant women and females undergoing a menstruation period. Due to the traditional and cultural setting of Fiji, women are unable to speak about these issues with others and, they usually have to take care of their reproductive needs in isolation or at night in evacuation centres (Suva, Informant 21, 5 April 2010).

Post disaster assessments show increased violence against women and girls in and around evacuation centres during and after disasters, with elderly women and girls with disabilities being more at risk. This is because socio-cultural factors such as gender inequalities, power relations, and discrimination of marginalised persons, further amplify the risk to domestic and other forms of gender-based violence and child abuse. Incidents of rape, sexual exploitation and incest among women and children in evacuation centres have been reported during disaster emergencies in Fiji:

\section{Extract 17}

In the dark they have to go out and this places women in unsafe conditions. In evacuation centres women and children get exposed to sexual dangers - children's rights are ignored. In this country disaster management is not a very quick recovery for women and children (Suva, Informant 22, 7 April 2010). 
For example, the 2009 and 2013 floods increased incidences of domestic violence were reported generally due to additional stress, pressure and traumatic psychological experiences (UN Women 2013). Following, TC Winston, cases of rape were reported in the media outside of evacuation centres, while some women and girls engaged in sex work as a coping strategy (Charan et al. 2016). The financial burden after disasters also results in girls being forced to quit education or get married at an early age.

\subsubsection{The hidden burden of food insecurity}

Traditional gender roles in patriarchal contexts coupled with the economic burden of providing for families, hinder women's livelihoods. While women have the traditional role in subsistence farming, coastal fisheries (e.g., collection of shellfish), children are responsible for planting and selling vegetable and sea produce 'part-time' outside of school hours and 'full-time' during school holidays. These traditional roles and responsibilities form the basis of income and subsistence within many Fijian households. Floods impact the productivity of rivers, fertility of catchments, family gardens and loss of coastal fisheries. Women recalled their experiences of loss of basic services and food shortages during floods:

\section{Extract 18}

People cannot buy groceries. Groceries become expensive. Old stock and poisoned food are sold. That is when the health inspectors check the food supplies. They tell us not to buy such food. So, some poisoned foods and spoilt ones are thrown away. Poor people collect the poisoned food, but Fijians from squatters also collect the poisoned food (Nadi, Informant 36, 17 March 2010).

Following floods and cyclones, women and children are driven to inner reaches of mangroves or outer areas of shoreline areas in search of river and marine fisheries to feed their households or for selling. Even long after floods and cyclones, municipal markets remain closed, forcing women and children to sell their produce on streets. These unsafe conditions expose women and children to physical and sexual harassment. Women are also responsible for most domestic chores. Cyclones and floods stretch domestic responsibilities and increase their workloads and burden of responsibility to support children. Mothers have to evacuate children to higher grounds, take care of sick children, clean houses and support children's return to schools as men look for other forms of employment. Woman in the FGD shared their experiences of 'over stretch' of burden of responsibilities leaving them overworked and tired:

\section{Extract 19}

There is already an unequal distribution of responsibilities within households and the family responsibilities. Climate change and floods aggravates the dynamics of such a family. Women are always affected by natural disasters. The men get aggressive. Women are more prone to violence when food is not provided. Women are the poorest of the poor and because of this, women are affected by 
disasters and climate change as they do not have the financial capacity to adapt to the floods (Suva, Informant 22, 7 April 2010).

\section{Extract 20}

Women have to clean up the flood. They have to decide where to set things. Women start from the very bottom, what to bring in the house after floods and how-to set-up the house. Everything has to be done by the women. From cleaning the house to finding food and taking sick children after floods to hospital (Nadi, Informant 39, 17 March 2010).

\section{Extract 21}

Men [in squatter settlements] have temporary jobs and heir dependents survive on daily wages. They have no fixed salaries. Some men still have jobs after floods, but women rely on handouts (rescue services, relief items). Their houses are destroyed during floods and women are crippled to go to work, they lose income and in some cases their jobs (Nadi, Informant 38, 18 March 2010).

Fiji's acute vulnerability to rising sea-levels and coastal erosion has also led the Government to plan and undertake climate change related relocation and settlement (GoF 2018). To date, a total of three villages have already been successfully fully relocated in Fiji, two partially relocated and two more in the initial stages of relocation (Fiji TV 2018). The Fiji Green Growth Framework has earmarked around 42 more villages for potential relocation, with local assessments underway (GoF 2014). Relocation in Vunidogoloa Village has poorly accounted for women's needs, with female members of households less likely to be involved in decision-making, negative impacts to livelihoods and adverse sentiments relating to loss of attachment to land and identify, heightened feelings of fear and impact to health (Piggott-McKellar et al. 2019). Relocation to higher ground has resulted in women not being able to access their coastal resources for fishing making them more dependent on their spouses for food. This is due to the new village being too far from their coastal resources, and women's responsibilities of the children restricting them from taking lengthy absences to fish (UN Women 2016).

Mental health impacts can also occur pre-disasters. Women and children in Fiji experience heightened feelings of anxiety levels, negative emotions, sadness in the context of their local ecology, fear for the younger generation, hopelessness, and helplessness. This is characterised by social fear, trauma and emotions that are echoed through the perceptions of disasters in vulnerable villages. As one religious leader shared the collective experiences of parishioners, where people associate floods and cyclones with loss of belongings, death of family members, food and water insecurity, hunger and suffering, periods of increased crime and loss of livelihood and income:

\section{Extract 22}

As soon people hear about floods, they run to higher places. Women take the children to hospital and schools. Husbands stay behind in house. People put their vehicles in higher places. The Meteorology 
Office and news tell people quickly, so deaths are reduced. Climate is changing, there is more rain, the earth cannot soak so much rain which is a lot now days (Nadi, Informant 37, 18 March 2010.

Research on vulnerable locations in Nadi town showed negative psychosocial and emotional phenomena triggered by approaching extreme events and weather warnings amongst women. Within hours after intense rain, cyclone and flood warnings are issued to residents, people start vacating the town and lowlying areas (Chandra and Gaganis 2016). Among women living in informal settlements and marginal farming societies, fear is also characterised by the reluctance to evacuate homes. Farmers and small businesses are anxious about leaving their belongings, informal settlements reluctant to seek assistance from 'community' networks, while women are apprehensive about speaking about their health conditions and needs due to their social standing. More frequent dry spells and flooding in Fiji affecting many locations have also meant that traditional knowledge and coping mechanisms are becoming less reliable. Women's eroding traditional and local knowledge on coping mechanisms, lack of access to financial resources, poor participation in decision-making and weak access to information further heightens their feeling of insecurity and exposure to climate-induced disasters.

The Fijian case study provides an example of mental health factors associated with hardship triggered by disasters and psychological impacts of climate change on women. Even though Fiji is undertaking climate-induced relocation and adaptation, increasing severity of disaster and climate impacts places enormous challenge on women and children, owing to their different sensitivities and differentiated emotional and coping capacities. Women and men may be equally aware of climate risks, but women and children experience a higher incidence of gender-based violence, impact on livelihood and have negative emotions related to periods of disasters.

\subsection{The case of Vanuatu: Stories of hardship and recovery}

Vanuatu is an archipelago of 83 islands in the South-West Pacific. With just under 300,000 people spread across the country, Vanuatu is considered to have high exposure to environmental changes and is consistently ranked as the country with the highest disaster risk in the World Risk Report for the last few years (Day et al. 2019). It is characterised as a SIDS and a Least Developed Country, ranked 131 out of 187 countries in the latest Human Development Index (United Nations 2015). As such, its people are seen on these various barometers as being abjectly poor and vulnerable. To visit such societies however paint a contrasting picture with resilience, extensive traditional knowledge, Kastom (traditional culture or custom) and pride all conspicuous. One of the authors spent three months in Vanuatu in 2018. During this time, fieldwork was undertaken with women $(n=53)$ working at various marketplaces around Efate (the main island in Vanuatu, home to the capital of Port Vila). Ten FGDs were undertaken with a view to explore experiences of climatic events and how these women have responded, including the role of marketplaces, as a traditional development-oriented initiative, in building resilience against climate change and disasters (see Clissold et al. 2020; McNamara et al. 2020).

Through the FGDs with several of these marketplace vendors, emerging stories of loss and recovery emerged. Marketplaces are a crucial source of income for numerous households across Vanuatu, and 
women make up the vast majority of marketplace vendors (Busse and Sharp 2019). Household - and indeed, women's - dependency on climate-sensitive crops and other produce can "lock households into a system that is disproportionately sensitive to shocks" (Clissold et al. 2020: 102; see also Bolwig et al. 2010). This case study focusses on women because their voices, experiences and needs in relation to disasters more broadly are often ignored at both micro and macro scales, despite their wealth of knowledge and capacities when it comes to disasters.

\subsubsection{Stories of loss and hardship}

Marketplace vendors who participated in this study emphasised the risks posed by cyclones and droughts for livelihoods and shared their experiences and stories of loss and hardship. Cyclone Pam was a category 5 cyclone that made landfall over the dispersed islands of Vanuatu on 13 March 2015 - the worst cyclone to make landfall in the country - causing a number of deaths, displacing around 65,000 people, devastating $80 \%$ of rural livelihoods including $96 \%$ of food stocks (Esler 2015). For these women vendors, they shared stories about how Cyclone Pam had devastating impacts on their gardens, homes and livelihoods, all of which were destroyed:

\section{Extract 23}

All the things from the garden went down. House also gone away. (Epule village FGD 2018).

Almost 10 houses in the village. /.../ everything like coconut and mangos, and crops, all the nuts, everything /.../ there's nothing there. until today, all the mangos are still not, haven't bared fruit (Nguna village FGD 2018).

The destruction to houses, gardens and public infrastructure was extensive. The women told the story about how they had to first try and clean their homes and go to the gardens to see if anything could be salvaged for their families to survive on over the coming days and weeks. But there were added challenges of even accessing the gardens:

\section{Extract 24}

They found it very difficult to enter the garden because all the woods are blocking the entrance to their garden. You had to go over the garden or go over the big trees (Emua village FGD 2018).

Once the men were able to clear the garden entrances and remove the large trees, the women returned to their gardens to start the clean-up and eventual re-planting. However, this whole process had a significant impact on their ability for self-subsistence and their livelihoods given that selling fresh produce and handicrafts at marketplaces was what they did to support their family. Cyclone Pam had a significant impact on their lives and livelihoods and halted marketplace operations for many months and in some cases up to a year or more: 


\section{Extract 25}

After clearing the gardens, plant and it took them one year to actually come back to the market and start selling (Emua village FGD 2018).

Later in 2015, as people were in the process of recovery, the worst drought in 20 years followed, significantly exacerbating impacts. This was a heart-breaking situation for the women as: "the crops are all destroyed" (Emua village FGD 2018). For these women, growing crops following Cyclone Pam was a critical matter for survival but the subsequent drought then caused the crops to dry out or become "stunted" (Emua village FGD 2018). In these cases, many of the women relied on only a few key crops that were more drought-tolerant such as manioc and taro and waited for the rain to eventually come.

\subsubsection{Stories of recovery and hope}

This case study reveals how stories of recovery and healing for these women have revolved around social networks, changing agricultural behaviours, and diversifying livelihood streams for a more hopeful future.

Women work together. In time of crisis, this is particularly pertinent. These women vendors provided details about how their social networks extended across islands, and therefore can be useful to rely on in times of produce shortages. The networks developed between women from different islands is impressive and useful in overcoming issues with peripherality. These social networks can also act as safety nets for women when they may temporarily be low on stock for various reasons (i.e. weather, other pressures on time). This has become a particularly important recovery strategy following Cyclone Pam:

\section{Extract 26}

She make orders to other islands, to other women. So family members that are in Paama or Ambrym that have nuts, or Epi... they send it over to her and then she resells it and gets her money, but she pays them... oh they do exchange with food. They package them a box of food for that muma and that muma sends things over (Nguna village FGD 2018).

Women are also key agents for ensuring equity and inclusiveness in disaster recovery and adaptation as they consistently help those less abled (i.e. widows, disabled women) to recover following major events and be involved in the gardens and marketplace.

One of the big changes made to these women following Cyclone Pam was the need to save their seeds. This wasn't a common practice prior to Cyclone Pam but given the often lengthy waits for supplies to arrive to the village from various agencies, including critical seeds and tools, the women now pro-actively collect their own seeds following each harvest. Another key change to agricultural practices is to plant smaller, multiple gardens near the home:

\section{Extract 27}


I know that if one disaster comes now, l've saved some seeds. /.../ Don't wait [for external assistance] (Epau village FGD 2018).

\section{Extract 28}

Like big, massive gardens will go up hill, but these ones like smaller ones, close. So those that can withstand the cyclone can be up there, so the change location of crops (Emua village FGD 2018).

As a way of recovering to significant climatic events and preparing for the future as part of a more hopeful future, women vendors are also becoming entrepreneurs and diversifying their livelihoods and income streams; "I paint fabrics and then I sew them the dresses" and "They have built businesses at their homes, little canteens" (Epule village FGD 2018):

\section{Extract 29}

It really impacts the life of women in the community. They are doing businesses like food selling, handicraft. They are doing printing, painting and all this stuff just for money before they came back to their communities and they do the same thing as well. This is a very big change that l've seen (Silae Vanua Market Vendor Association FGD 2018).

Women's stories of loss, hardship, recovery and hope are important. The stories reveal how women are at the frontline of disaster response and recovery with extensive knowledge, skills and social networks. These capacities and capabilities should be recognised and built upon but not without also addressing underlying root causes of vulnerability and inequitable power structures that over-burden and constrain women's overall welling.

\section{Footnote:}

[4] For more details on each methodological approach, sampling, and interviewing sessions see AyebKarlsson et al. 2016, 2020 and Ayeb-Karlsson 2020a and 2020b.

\section{Discussion}

The study of loss, perceived threat, and despair to one's identity in relation to environmental stress and livelihood shifts is not new. Gender as a critical factor in shaping environmental vulnerability has however often focused on male loss of productive capacity in natural resource-based livelihoods such as farming and fishing. The distress caused by environmental change is a global issue that no socio-cultural setting can escape. Even though societies may adapt to global environmental changes, their adaptation strategies can include irreversible losses of things that people value or trade-offs.

The case studies illustrate spiralling non-economic losses, that directly and indirectly eroded women's wellbeing while impeding coping, risk reduction and adaptation actions. In Bangladesh these related to gendered (im)mobility experiences of rural-urban migration and cyclone strikes, while in Fiji and Vanuatu 
gendered vulnerabilities before and after the disasters were observed. Women and girls faced patriarchal social risks and vulnerabilities, stemming from gender inequity, that did not affect men in the same way. Meanwhile, the non-economic losses were shaped by increased exposure to unsafe conditions and workload, food insecurity, loss of employment opportunities, and loss of access to decision-making.

Women are more likely to be exposed to violence, rape or physical and sexual harassment, that leave behind deep permanent emotional scars and damages that take a lifetime to heal and recover. Unlike material losses, the impacts upon women's wellbeing leave long lasting non-material issues such as mental health challenges. Evidence from the stories captured in the two island settings indicate trends around the heightened stress women face due to food insecurity. In our gendered societies, food preparation is generally a responsibility that falls upon women. As illustrated in the Fijian storylines, the loss of food may compound social tensions in the households, making them vulnerable to disproportional risks of gendered-based violence after the disasters. In Vanuatu, women described deep grief and feeling inadequate after losing their kitchen gardens and food insecurity. The gardens represented a more profound loss, including the erosion of their individual self-efficiency, independence, agency, and ability to endure and recover from climate-induced stress.

In the context of the Asia-Pacific region, the loss of social safety nets, less control over natural resources, deterioration of wellbeing, forced sex work or early marriage to support a family financially can impossibly be measured in monetary terms. Non-economic losses and damages are often characterised as those that are difficult or impossible to estimate and quantify (the lost amount) or valorise (the losses). The storylines illustrated non-monetary losses and how it was difficult to put a value and quantify elements such as honour and dignity in the context of Bangladesh. These losses were often triggered by traumatic experiences such as livelihood shift, abandonment of children, or child marriages. In this way, certain irreplaceable losses were context specific and associated with local culture and value systems.

The gender dimension to climate-induced loss and damage is highly subjective, closely mediated by cultural circumstances and social issues such as equity, justice, power relations, rights, welfare and basic services. People's subjective understanding of climate-induced losses can therefore result in very different personal experiences of loss whilst being exposed to similar climate hazards in similar societies and regions. In this way, more anthropological understandings of loss built on local narratives can provide policymakers with key insights on what is valued, how people deal with irreplaceable losses, and what damages are lasting. Personal narratives cannot be subjected to standardised measurements and statistical or economic assessments. However, storylines can be recorded and act as stable steppingstones to support adequate adaptation and risk reduction efforts in vulnerable locations, incorporating elements of non-economic losses.

In Vanuatu and Bangladesh, narratives around recovery and healing emerged. This represents an area of research that need to be prioritised in the future. An enhanced understanding of how people recover from the grief of the losses and heal over time can provide valuable tools supporting more inclusive policy 
solutions. Climate policy better incorporating counselling, assessment of damage and wellbeing erosion, psychological care and mental health services for trauma is key to support vulnerable populations across the world.

In Vanuatu, support groups comprising of women were available in the marketplaces to share the emotional and psychosocial burden. Similarly, in Fiji, in the absence of formal psychological care, women-led support groups enabled others to grieve and exchange stories about their traumatic experiences, and gather strength to boost their coping capacities to respond and recover from the climateinduced impacts. Safe, caring, and stable social networks needs to be strengthened and may provide solutions for people to minimize and address future losses and damages. As observed in the storylines captured in Bangladesh, formal post-disaster mental health and psychosocial support services are often lacking leading to devastating impacts upon societies for several generations to come.

\section{Conclusion}

The limits to adaptation literature body provides a basis for understanding ways to measure loss and damage within climate change policies. Yet in the context of non-economic losses, scientists and practitioners have devoted limited time and effort to design methods that can capture mental health consequences for specific vulnerable groups. To better understand the consequences of non-economic losses and damages associated with the adverse gendered effects of climate- and weather-related natural hazards, this article attempted a bottom-up people-centred research to storytelling approach in Bangladesh, Fiji and Vanuatu. In conclusion, loss and damage may trigger traumatic stress, anxiety, increase gender-based violence, food shortages, and child marriages. These impacts when left unaddressed can have long-term negative consequences for women such as leading to mental ill-health, including trauma, anxiety, stress, depression and loss of social identify and networks.

The empirical insights provide evidence to social networks and healing processes that harness recovery and self-confidence of women. A storytelling approach effectively support the much-needed empirical body of evidence around Loss and Damage. People-centred research designs still receive little attention in the area of climate change, as the general perception appears to be that the right set of indicators will be the 'panacea for all disease'. National policies that address non-economic losses and damages must better prioritise women and other marginalised groups. A stronger acknowledgement within climate policy must accept that losses and damages of what people value the most, cannot and should not be measured according to monetary market terms. Certain elements in life are invaluable, and the fact that we do not attempt to measure them, is precisely what gives them a unique value.

\section{Declarations}

\section{Acknowledgements}

Omitted for peer review. 


\section{Funding}

No specific funding to declare.

\section{Competing or Conflicts of interest}

The authors declare no competing or conflicts of interest.

\section{Availability of data and material}

Primary data available upon request.

\section{Code availability}

Not applicable.

\section{Ethics approval}

All procedures performed were in accordance with the ethical standards of the institutions at which the studies were conducted and ethical approval was obtained from their Research Governance and Ethics Committees.

\section{Consent to participate}

All research participants have agreed to take part in the study through written informed consent.

\section{Consent for publication}

The authors give the publisher the permission to publish the work.

\section{Authors' contributions}

SAK developed and led the conceptual and theoretical idea of the article. All three authors gathered primary data, led data the analysis and drafted one case study section each. All three authors contributed to the writing of the manuscript and engaged in revisions to critically shape the manuscript into its final stage.

\section{References}

1. Adeola, F. O. (2009). Mental Health \& Psychosocial Distress Sequelae of Katrina: An Empirical Study of Survivors. Human Ecology Review, 16(2), 195-210.

2. Adger, W. N. (2003). Social capital, collective action, and adaptation to climate change. Economic Geography 79(4):387-404.

3. Adri, N., and Simon, D. (2018). A tale of two groups: focusing on the differential vulnerability of "climate-induced" and "non-climate-induced" migrants in Dhaka City. Climate and Development, 
10(4), 321-336. doi:10.1080/17565529.2017.1291402

4. Ahmed, K. J., Haq, S. M. A., \& Bartiaux, F. (2019). The nexus between extreme weather events, sexual violence, and early marriage: A study of vulnerable populations in Bangladesh. Population and Environment, 40(3), 303-324. https://doi.org/10.1007/s11111-019-0312-3

5. Akhter, S., Rutherford, S., Kumkum, F. A., Bromwich, D., Anwar, I., Rahman, A., and Chu, (2017). Work, gender roles, and health: neglected mental health issues among female workers in the ready-made garment industry in Bangladesh. International Journal of Womens Health 9: 571-579.

Doi:10.2147/ijwh.s137250

6. Akhter, S. R., Sarkar, R. K., Dutta, M., Khanom, R., Akter, N., Chowdhury, M. R., \& Sultan, (2015). Issues with families and children in a disaster context: A qualitative perspective from rural Bangladesh. International Journal of Disaster Risk Reduction, 13, 313-323.

https://doi.org/10.1016/j.ijdrr.2015.07.011.

7. Alam, K., Rahman, M.H. (2014). Women in natural disasters: a case study from southern

8. coastal region of Bangladesh. International Journal of Disaster Risk Reduction 8: 68-82. doi: 10.1016/j.j.j.jr.2014.01.003

9. Albrecht, G., Sartore, G.-M., Connor, L., Higginbotham, N., Freeman, S., Kelly, B., . . Pollard, G. (2007). Solastalgia: the distress caused by environmental change. Australasian psychiatry, 15(sup1), S95S98.

10. Ayeb-Karlsson, S. (2020a). 'I do not like her going to the shelter': Stories on gendered disaster (im)mobility and wellbeing loss in coastal Bangladesh. International Journal of Disaster Risk Reduction. 50: 101904. https://doi.org/10.1016/j.ijdrr.2020.101904

11. Ayeb-Karlsson, S. (2020b). 'When we were children we had dreams, then we came to Dhaka to survive': urban stories connecting loss of wellbeing, displacement and (im) mobility. Climate and Developmenthttps://doi.org/10.1080/17565529.2020.1777078

12. Ayeb-Karlsson, S. (2020c). No Power without Knowledge: A Discursive Subjectivities Approach to Investigate Climate-Induced (Im)mobility and Wellbeing. Social Sciences9(6), 103.

http://dx.doi.org/10.3390/socsci9060103

13. Ayeb-Karlsson, S., Kniveton, D. and Cannon, T. (2020). Trapped in the prison of the mind: notions of climate-induced (im)mobility decision-making and wellbeing from an urban informal settlement in Bangladesh. Palgrave Communication 6(62): 1-15, https://doi.org/10.1057/s41599-020-0443-2

14. Ayeb-Karlsson, S., Kniveton, D., Cannon, T., van der Geest, K., Ahmed, I., Derrington, E. M., ... Opondo, D. (2019). I will not go, I cannot go: Cultural and social constraints to disaster preparedness in Asia, Africa and Oceania Disasters. doi: https://doi.org/10.1111/disa.12404

15. Ayeb-Karlsson, S., van der Geest, K., Ahmed, I., Huq, S., and Warner, K. (2016). A people-centred perspective on climate change, environmental stress, and livelihood resilience in Bangladesh. Sustainability Science, 11(4), 1-16. doi:https://doi.org/10.1007/s11625-016-0379-z

16. Barnett, J. (2017). The dilemmas of normalising losses from climate change: Towards hope for Pacific atoll countries. Asia Pacific Viewpoint, 58(1), 3-13. Doi:10.1111/apv.12153 
17. Barnett, J., Tschakert, P., Head, L., and Adger, W. N. (2016). A science of loss. Nature Climate Change 6(11): 976. doi:https://doi.org/10.1038/nclimate3140

18. Barnett, J., Evans, L. S., Gross, C., Kiem, A. S., Kingsford, R. T., Palutikof, J. P., . . Smithers, S. G. (2015). From barriers to limits to climate change adaptation: path dependency and the speed of change. Ecology and society 20(3). Doi:10.5751/ES-07698-200305

19. Berry, H. L., Waite, T. D., Dear, K. B. G., Capon, A. G., and Murray, V. (2018). The case for systems thinking about climate change and mental health. Nature Climate Change, 8(4), 282-290.

Doi:10.1038/s41558-018-0102-4

20. Binu, J., Mawson, A. R., Payton, M., Guignard, J.C. (2008). Disaster mythology and fact: Hurricane Katrina and social attachment. Public Health Rep 123:555-566.

21. Bolwig, S., Ponte, S., Du Toit, A., Riisgaard, L., Halberg, N. (2010). Integrating poverty and environmental concerns into value-chain analysis: a conceptual framework. Development Policy Review 28 (2), 173-194. https://doi.org/10.1111/j.1467-7679.2010.00480.x.

22. Boyd, E., James, R. A., Jones, R. G., Young, H. R. and Otto, F. E. L. (2017). A typology of loss and damage perspectives. Nature Climate Change 7(10): nclimate3389. Doi: 10.1038/nclimate3389.

23. Busse, M. and Sharp, T.L.M. (2019). Marketplaces and morality in Papua New Guinea: Place, personhood and exchange. Oceania 89(2): 126-153. https://doi.org/10. 1002/ocea.5218

24. Butala, N. M., VanRooyen, M. J., and Patel, R. B. (2010). Improved health outcomes in urban slums through infrastructure upgrading. Social Science \& Medicine, 71(5), 935-940.

Doi:10.1016/j.socscimed.2010.05.037

25. Butler, C. D., Bowles, D., Mclver, L., and Page, L. (2014). Mental Health, Cognition and the Challenge of Climate Change. In Climate Change and Global Health. CABI.

26. Cattaneo, M. D., Galiani, S., Gertler, P. J., Martinez, S., and Titiunik, R. (2009). Housing, Health, and Happiness. American Economic Journal-Economic Policy, 1(1), 75-105. Doi:10.1257/pol.1.1.75

27. Chand, S.S., Tory, K.J, Ye, H. and Walsh, K.J.E. (2016). Projected Increase in El Niño-driven Tropical Cyclone Frequency in the Pacific. Nature Climate Change 7: 123-27.

28. Chandra, A. and Gaganis, P. (2015). Deconstructing vulnerability and adaptation in a coastal river basin ecosystem: a participatory analysis of flood risk in Nadi, Fiji Islands. Climate and Development 8(3): 256-269.

29. Charan, D., Kaur, M. and Singh, P. (2016). Indigenous Fijian Women's Role in Disaster Risk Management and Climate Change Adaptation. Pacific Asia Inquiry 7(1): 106-122.

30. Clayton, S., Devine-Wright, P., Stern, P.C., Whitmarsh, A. C., Steg, L., Swim, J., and Bonnes, M. (2015). Psychological research and global climate change. Nature Climate Change 5: 640-646.

31. Clissold R, Westoby, R. and McNamara, K.E. (2020). 'Women as recovery enablers in the face of disasters in Vanuatu', Geoforum, 113, 101-110.

32. Conway, D., Nicholls, R. J., Brown, S., Tebboth, M. G. L., Adger, W. N., Ahmad, B., . . Wester, P. (2019). The need for bottom-up assessments of climate risks and adaptation in climate-sensitive regions. 
Nature Climate Change. doi:10.1038/s41558-019-0502-0

33. Cunsolo, A., and Ellis, N. R. (2018). Ecological grief as a mental health response to climate changerelated loss. Nature Climate Change, 8(4), 275-281. https://doi.org/10.1038/s41558-018-0092-2

34. Cutter, S.L. (2017). The forgotten casualties redux: women, children, and disaster risk. Global Environmental Change 42, 117-121. 10.1016/j.gloenvcha.2016.12.010

35. Davis, T. E., Grills-Taquechel, A. E., and Ollendick, T. H. (2010). The Psychological Impact From Hurricane Katrina: Effects of Displacement and Trauma Exposure on University Students. Behavior Therapy, 41(3), 340-349. doi:10.1016/j.beth.2009.09.004

36. Day, S., Forster, T., Himmelsbach, J., Korte, L., Mucke, P., Radtke, K., Thielborger, P.,

37. Weller, D., (2019). World Risk Report 2019. Retrieved from Bundnis Entwicklung Hilft and Ruhr University Bochum - Institute for International Law of Peace and Armed Conflict website: https://reliefweb.int/sites/reliefweb.int/files/resources/WorldRiskReport-2019_Online_english.pdf.

38. De, P. K. and Murshid, N. S. (2018). Associations of intimate partner violence with screening for mental health disorders among women in urban Bangladesh." International Journal of Public Health 63(8):913-921. Doi: 10.1007/s00038-018-1139-x.

39. Du Bray, M., Wutich, A., Larson, K.L., White, D.D. and Brewis, A. (2019). Anger and Sadness: Gendered Emotional Responses to Climate Threats in Four Island Nations. Cross-Cultural Research 53(1): 5886.

40. Enarson, E. (1998). Through women's eyes: A gendered research agenda for disaster social science. Disasters, 22(2), 157-173. doi:https://doi.org/10.1111/1467-7717.00083

41. Esler, S., (2015). Post-Disaster Needs Assessment - Tropical Cyclone Pam, March 2015. Port Vila: Government of Vanuatu. Retrieved from: https://reliefweb.int/sites/reliefweb. int/files/resources/vanuatu_pdna_cyclone_pam_2015.pdf.

42. Etzold, B. (2016). Migration, Informal Labour and (Trans) Local Productions of Urban Space - The Case of Dhaka's Street Food Vendors. Population Space and Place, 22(2), 170-184. doi:10.1002/psp.1893

43. Ezeh, A., Oyebode, O., Satterthwaite, D., Chen, Y.-F., Ndugwa, R., Sartori, J., . . Lilford, R. J. (2017). The history, geography, and sociology of slums and the health problems of people who live in slums. The Lancet, 389(10068), 547-558. doi:https://doi.org/10.1016/S0140-6736(16)31650-6

44. Farbotko, C., and Lazrus, H. (2012). The first climate refugees? Contesting global narratives of climate change in Tuvalu. Global Environmental Change, 22(2), 382-390.

45. Fiji TV (2018). Seruiratu Launches Fiji's Relocation Guidelines. Suva, Fiji: Fiji Television Ltd. Available at https://www.fijione.tv/news-posts/seruiratu-launches-fijis-relocation-guidelines/ [accessed 20.01.2021].

46. Fitch, T. J., Yu, X., Chien, L. C., Karim, M. M., and Alamgir, H. (2018). Traumatic life events and development of post-traumatic stress disorder among female factory workers in a developing country. International Journal of Social Psychiatry 64(4): 351-358. Doi:

$10.1177 / 0020764018761502$.

Page 24/29 
47. Fothergill, A. (1996). Gender, risk, and disaster. International journal of mass emergencies and disasters, 14(1), 33-56.

48. GoF (2018). Planned Relocation Guidelines A framework to undertake climate change related relocation. Suva, Fiji, Ministry of Economy, Government of Republic of Fiji.

49. GoF (2017). Climate Vulnerability Assessment - Making Fiji Climate Resilient. Suva, Fiji, Government of Republic of Fiji GoF (2014). Green Growth Framework for Fiji: Restoring the Balance in Development that is Sustainable for Our Future. Suva, Fiji, Ministry of Strategic Planning, National Development and Statistics, Government of Republic of Fiji.

50. Gruebner, O., Khan, M. M. H., Lautenbach, S., Muller, D., Kramer, A., Lakes, T., and Hostert, P. (2012). Mental health in the slums of Dhaka - a geoepidemiological study. BMC Public Health, 12. doi:10.1186/1471-2458-12-177

51. Gruebner, O., Khan, M. M. H., Lautenbach, S., Muller, D., Kraemer, A., Lakes, T., and Hostert, P. (2011). A spatial epidemiological analysis of self-rated mental health in the slums of Dhaka. International Journal of Health Geographics, 10. doi:10.1186/1476-072x-10-36

52. Hayward, G. and Ayeb-Karlsson, S. (2021). 'Seeing with empty eyes': A systems approach to understand climate change and mental health in Bangladesh. Climatic Change. Forthcoming.

53. Heintz, H., Kirch, L., Kuppers, B., Mann, H., Mischo, F., Mucke, P., Pazdzierny, T., Prutz, R., Radtke, K., Strube, F. and Weller, D. (2018). World Risk Report 2018, Bündnis Entwicklung Hilft and Ruhr University Bochum, Berlin, Germany, https://reliefweb.int/sites/reliefweb.int/files/resources/WorldRiskReport-2018.pdf

54. Huggel, C., Stone, D., Eicken, H., and Hansen, G. (2015). Potential and limitations of the attribution of climate change impacts for informing loss and damage discussions and policies. Climatic change, 133(3), 453-467. Doi:10.1007/s10584-015-1441-z

55. Hunter, E., Thusanth, S., McCalman, J. and Gopalkrishnan, N. (2015a). Mental health in the island nations of the Western Pacific: a rapid review of the literature Aus. Psych. 23 9-12.

56. Hunter, L. M., Luna, J. K., and Norton, R. M. (2015b). Environmental dimensions of migration. Annual Review of Sociology, 41, 377-397.

57. IPCC (2018). Hoegh-Guldberg, O., D. Jacob, M. Taylor, M. Bindi, S. Brown, I. Camilloni, A., ... Zhou, G. Chapter 3: Impacts of $1.5^{\circ} \mathrm{C}$ Global Warming on Natural and Human Systems. In: Global Warming of $1.5^{\circ} \mathrm{C}$. An IPCC Special Report on the impacts of global warming of $1.5^{\circ} \mathrm{C}$ above pre-industrial levels and related global greenhouse gas emission pathways, in the context of strengthening the global response to the threat of climate change, sustainable development, and efforts to eradicate poverty [Masson-Delmotte, V., P. Zhai, H.-O. Pörtner, D. Roberts, J. Skea, P.R. Shukla, ... Waterfield, T. (eds.)]. IPCC: In Press.

58. IPCC (2014). Climate Change 2014: Impacts, Adaptation, and Vulnerability. Part B: Regional Aspects. Contribution of Working Group II to the Fifth Assessment Report of the Intergovernmental Panel on Climate Change [Barros, V.R., C.B. Field, D.J. Dokken, M.D. Mastrandrea, K.J. Mach, T.E. Bilir, M. Chatterjee, K.L. Ebi, Y.O. Estrada, R.C. Genova, B. Girma, E.S. Kissel, A.N. Levy, S. MacCracken, P.R. 
Mastrandrea, and L.L. White (eds.)]. Cambridge, United Kingdom and New York, NY, USA: Cambridge University Press.

59. Izutsu, T., Tsutsumi, A., Islam, A. M., Kato, S., Wakai, S., and Kurita, H. (2006). Mental health, quality of life, and nutritional status of adolescents in Dhaka, Bangladesh: Comparison between an urban slum and a non-slum area. Social Science \& Medicine, 63(6), 1477-1488. doi:10.1016/j.socscimed.2006.04.013

60. Jordan, J.C. (2018) Deconstructing resilience: why gender and power matter in responding to climate stress in Bangladesh. Climate and Development 1-13. https://doi.org/10.1080/17565529.2018.1442790

61. Juran, L., and Trivedi, J. (2015). Women, Gender Norms, and Natural Disasters in Bangladesh. Geographical Review, 105(4), 601-611.

62. Kelman, I. (2015). Difficult decisions: Migration from Small Island Developing States under climate change. Earth's Future, 3(4), 133-142. doi:10.1002/2014EF000278

63. Kelman, I., Ayeb-Karlsson, S., Rose-Clarke, K., Prost, A., Ronneberg, E., Wheeler, N. and Watts, N. (2021). A review of mental health and wellbeing under climate change in smallisland developing states (SIDS). Environmental Research Letters. https://doi.org/10.1088/1748-9326/abe57d

64. Khan, A. M., and Flora, M. S. (2017). Maternal common mental disorders and associated factors: a cross-sectional study in an urban slum area of Dhaka, Bangladesh. International Journal of Mental Health Systems, 11. doi:10.1186/s13033-017-0129-3

65. Le Blanc, D. (2015). Towards integration at last? The sustainable development goals as a network of targets. New York, UNDESA.

66. Live and Learn and CARE (2016). Rapid Gender Analysis Tropical Cyclone Winston Fiji. Suva, Fiji, Live and Learn and CARE

67. Mberu, B., Wamukoya, M., Oti, S., and Kyobutungi, C. (2015). Trends in causes of adult deaths among the urban poor: evidence from Nairobi urban health and demographic surveillance system, 20032012. Journal of Urban Health, 92(3), 422-445. doi:https://doi.org/10.1007/s11524-015-9943-6

68. McNamara, K. E., and Jackson, G. (2019). Loss and damage: A review of the literature and directions for future research. Wiley Interdisciplinary Reviews-Climate Change, 10(2). doi:10.1002/wcc.564

69. McNamara, K. E., Westoby, R., and Chandra, A. (2021). Exploring climate-driven non-economic loss and damage in the Pacific Islands. Current Opinion in Environmental Sustainability, 50, 1-11. https://doi.org/10.1016/j.cosust.2020.07.004

70. McNamara K.E., Clissold, R. and Westoby, R. (2020). 'Marketplaces as sites for the developmentadaptation-disaster trifecta: Insights from Vanuatu', Asia Pacific Viewpoint, 61 (3), 566-576. https://doi.org/10.1111/apv.12293

71. McNamara, K. E., Olson, L. L., and Rahman, M. A. (2016). Insecure hope: the challenges faced by urban slum dwellers in Bhola Slum, Bangladesh. Migration and Development, 5(1), 1-15.

72. Mechler, R., and Schinko, T. (2016). Identifying the policy space for climate loss and damage. Science, 354(6310), 290-292. doi:10.1126/science.aag2514 
73. Methmann, C., and Oels, A. (2015). From 'fearing' to 'empowering' climate refugees: Governing climate-induced migration in the name of resilience. Security Dialogue, 46(1), 51-68.

74. Morrissey, J., and Oliver-Smith, A. (2013). Perspectives on Non-Economic Loss and Damage: Understanding values at risk from climate change. Loss and Damage in Vulnerable Countries Initiative Report. Bonn, Germany, UNU-EHS.

75. Mullick, M. S. I., and Goodman, R. (2005). The prevalence of psychiatric disorders among 5-10 year olds in rural, urban and slum areas in Bangladesh. Social Psychiatry and Psychiatric Epidemiology, 4O(8), 663-671. doi:10.1007/s00127-005-0939-5

76. Nolet, E. (2016). 'Are you prepared?' Representations and Management of Floods in Lomanikoro, Rewa (Fiji). Disasters 40(4): 720-739.

77. NRC (2019). Overlapping vulnerabilities: the impacts of climate change on humanitarian needs. Oslo: Norwegian Red Cross.

78. Orcherton, D., Mitchell, D. and McEvoy, D. (2017). Perceptions of Climate Vulnerability, Tenure Security and Resettlement Priorities: insights from Lami Town, Fiji Islands. Australian Geographer 48(2): 235-254.

79. Paul, B. K., Rahman, M. K., and Rakshit, B. C. (2011). Post-Cyclone Sidr illness patterns in coastal Bangladesh: an empirical study. Natural hazards, 56(3), 841-852.

80. Parvin, K., Al Mamun, M., Gibbs, A., Jewkes, R., and Naved. R. T. (2018). The pathways between female garment workers' experience of violence and development of depressive symptoms. Plos One 13(11). doi: 10.1371/journal.pone.0207485.

81. Penning-Rowsell, E. C., Sultana, P., and Thompson, P. M. (2013). The 'last resort'? Population movement in response to climate-related hazards in Bangladesh. Environmental Science \& Policy, 27, Supplement 1, S44-S59. doi:http://dx.doi.org/10.1016/j.envsci.2012.03.009

82. Piggott-McKellar, A., McNamara, K.E., Nunn, P. and Sekinini, S. (2019). Moving People in a Changing Climate: Lessons from Two Case Studies in Fiji. Social Sciences 8(5): 133.

83. Piguet, E. Kaenzig, R. and J. Guélat, J. (2018). The uneven geography of research on "environmental migration". Population and Environment 39, 357-383. 10.1007/s11111-018-0296-4

84. Preston, C. J. (2017). Challenges and Opportunities for Understanding Non-economic Loss and Damage. Ethics Policy \& Environment, 20(2), 143-155. doi:10.1080/21550085.2017.1342962

85. Rahaman, M. A., Rahman, M. M., Bahauddin, K. M., Khan, S., and Hassan, S. (2018). Health Disorder of Climate Migrants in Khulna City: An Urban Slum Perspective. International Migration 56(5): 42-55. doi: 10.1111/imig. 12460.

86. Rashid, S.F., Michaud, S. (2000). Female adolescents and their sexuality: Notions of honour, shame, purity and pollution during the floods. Disasters 24: 54-70. doi: 10.1111/1467-7717.00131

87. Rataj, E., Kunzweiler, K., and Garthus-Niegel, S. (2016). Extreme weather events in developing countries and related injuries and mental health disorders - a systematic review. BMC Public Health, 16. doi:10.1186/s12889-016-3692 
88. Rezwana, N. and Pain, R. (2020). Gender-based violence before, during and after cyclones: Slow violence and layered disasters. Disasters. https://doi.org/10.1111/disa.12441

89. Rhodes, J., Chan, C., Paxson, C., Rouse, C. E., Waters, M., and Fussell, E. (2010). The impact of hurricane Katrina on the mental and physical health of low-income parents in New Orleans. The American journal of orthopsychiatry 80(2): 237-247. doi:10.1111/j.1939-0025.2010.01027.x

90. Rivers, J. (1982). Women and children last: an essay on sex discrimination in disasters. Disasters, 6(4), 256-267. doi: https://doi.org/10.1111/j.1467-7717.1982.tb00548.x

91. Roberts, E., and Huq, S. (2015). Coming full circle: the history of loss and damage under the UNFCCC. International Journal of Global Warming, 8(2), 141-157. doi:10.1504/ijgw.2015.071964

92. Ruback, R. B., Pandey, J., Begum, H. A., Tariq, N., and Kamal, A. (2004). Motivations for and satisfaction with migration - An analysis of migrants to new Delhi, Dhaka, and Islamabad. Environment and Behavior, 36(6), 814-838. doi:10.1177/0013916504264948

93. Ruback, R. B., Begum, H. A., Tariq, N., Kamal, A., and Pandey, J. (2002). Reactions to environmental stressors - Gender differences in the slums of Dhaka and Islamabad. Journal of Cross-Cultural Psychology, 33(1), 100-119. doi:10.1177/0022022102033001007

94. Singh, C. (2019). Moving in and out of vulnerability: interrogating migration as an adaptation strategy along a rural-urban continuum in India. The Geographical Journal. doi: 10.1111/geoj.12328.

95. Schwerdtle, P., Bowen, K., and McMichael, C. (2018). The health impacts of climate-related migration. Bmc Medicine, 16(1), 1. doi:https://doi.org/10.1186/s12916-017-0981-7

96. Stanley, S. K., Hogg, T. L., Leviston, Z., and Walker, I. (2021). From anger to action: Differential impacts of eco-anxiety, eco-depression, and eco-anger on climate action and wellbeing. The Journal of Climate Change and Health, 100003. https://doi.org/10.1016/j.joclim.2021.100003

97. Tschakert, P., Ellis, N. R., Anderson, C., Kelly, A., and Obeng J. (2019). One thousand ways to experience loss: A systematic analysis of climate-related intangible harm from around the world. Global Environmental Change 55: 58-72. doi: https://doi.org/10.1016/j.gloenvcha.2018.11.006.

98. Tschakert, P., Barnett, J., Ellis, N., Lawrence, C., Tuana, N., New, M., . . Pannell, D. (2017). Climate change and loss, as if people mattered: values, places, and experiences. Wiley Interdisciplinary Reviews: Climate Change, 8(5), e476. doi:10.1002/wcc.476

99. Tschakert, P., Tutu, R., and Alcaro, A. (2013). Embodied experiences of environmental and climatic changes in landscapes of everyday life in Ghana. Emotion, Space and Society, 7, 13-25. doi:https://doi.org/10.1016/j.emospa.2011.11.001

100. United Nations (2019). World Population Prospects 2019. New York, USA, United Nations. Available at https://population.un.org/wpp [accessed 20.09.2019].

101. United Nations (2015). The permanent mission of the Republic of Vanuatu to the United Nations. Retrieved from https://www.un.int/vanuatu/vanuatu/climate-change

102. [accessed 19.09.2019]. 
103. UNFCCC (2015). Adoption of the Paris Agreement. Draft decision-/CP.21. [Retrieved from: http://unfccc.int/resource/docs/2015/cop21/eng/l09r01.pdf] Geneva, UNFCCC.

104. UNFCCC (2013). Non-economic losses in the context of the work programme on loss and damage. Technical Paper. Bonn, Germany, UNFCCC.

105. UNDRR (2015). Sendai Framework for Disaster Risk Reduction 2015-2030. Sendai: UNISDR.

106. UN Women (2016). Time to Act on Gender, Climate Change and Disaster Risk Reduction. An overview of progress in the Pacific region with evidence from The Republic of Marshall Islands, Vanuatu and Samoa. Bangkok, Thailand UN Women.

107. UN Women (2013). The 2012 Fiji Floods: Gender Sensitivity in Disaster Management. Suva, Fiji, UN Women.

108. Unger, A., and Riley, L. W. (2007). Slum health: from understanding to action. Plos Medicine, 4(10), e295. doi: https://doi.org/10.1371/journal.pmed.0040295

109. Watts, N., Amann, M., Arnell, N., Ayeb-Karlsson, S., Beagley, J., Belesova, K., ... and Costello, A. (2021). The 2020 report of The Lancet Countdown on health and climate change: responding to converging crises. The Lancet. https://doi.org/10.1016/S0140-6736(20)32290-X

110. Watts, N., Amann, M., Ayeb-Karlsson, S., Belesova, K., ... and Costello, A. (2018). The Lancet Countdown on health and climate change: from 25 years of inaction to a global transformation for public health. The Lancet 391 (10120): 581-630. doi: https://doi.org/10.1016/S0140-6736(17)324649.

111. Wekesa, B. W., Steyn, G. S., and Otieno, F. A. O. (2011). A review of physical and socio-economic characteristics and intervention approaches of informal settlements. Habitat International, 35(2), 238-245. doi:10.1016/j.habitatint.2010.09.006

112. WHO (2018). COP24 special report: health and climate change. Geneva: World Health Organization. ISBN: 9241514973

113. Willox, A. C. (2012). Climate change as the work of mourning. Ethics and the Environment, 17 (2), 137-164. https://doi.org/10.2979/ethicsenviro.17.2.137

114. Wisner, B., Blaikie, P., Cannon, T., and Davis, I. (2004). At risk: natural hazards, people's vulnerability and disasters (Second ed.). London and New York: Routledge. 